\title{
Use of Triticum aestivum in open wound healing: a clinical, pathological, and tensiometric assessment in the rabbit model
}

\author{
[Uso de Triticum aestivum na cicatrização de feridas: um ensaio clínico, \\ histopatológico e tensiométrico em coelhos] \\ M.T. Tillmann ${ }^{1}$, A.O.C. Felix ${ }^{1}$, E.N. Mueller ${ }^{2}$, S.R. Felix ${ }^{1}$, G.H. Alves ${ }^{3}$, T.S. Ramos ${ }^{4}$, \\ R.A. Freitag ${ }^{5}$, C.G. Fernandes ${ }^{1}$, M.O. Nobre ${ }^{1}$ \\ ${ }^{1}$ Faculdade de Veterinária - Universidade Federal de Pelotas - Pelotas, RS \\ ${ }^{2}$ Instituto Federal Catarinense - Campus Concórdia, SC \\ ${ }^{3}$ Faculdade de Agronomia Eliseu Maciel - Universidade Federal de Pelotas - Pelotas, RS \\ ${ }^{4}$ Faculdade de Odontologia - Universidade Federal de Pelotas - Pelotas, RS \\ ${ }^{5}$ Centro de Ciências Químicas Farmacêuticas e de Alimentos - Universidade Federal de Pelotas - Pelotas, RS
}

\begin{abstract}
While Triticum sp. has been shown to act in wound healing, stimulating collagen synthesis by fibroblasts, the use of this plant extract has yet to be assessed in vivo, in commercially viable presentations. This study used rabbits and assessed, on days seven, 14, and 21, the presence or absence of granulation tissue and epithelialization, histopathological structures, and scar quality through the breaking and tension strength. Treatments, performed for 21 days, were aqueous extract of $T$. aestivum at a concentration of $2 \mathrm{mg} / \mathrm{mL}$ (group I) and $10 \mathrm{mg} / \mathrm{mL}$ (group II) and a nonionic cream (control group). We demonstrate that the formation of granulation tissue was not significantly different between treatments. In the analysis of epithelial tissue, wounds in group II differed from other treatments by day 7. On days 14 and 21 there was no significant clinical difference between groups. In the histopathological evaluation, scar quality and rupture strength did not differ between the groups in the studied period. In the tension strength evaluation, group I differed from the others, presenting a higher tension strength overall. The studied treatments did not differ regarding healing evolution of the skin wounds, but $T$. aestivum extract, at $2 \mathrm{mg} / \mathrm{mL}$, presents better results in the tension strength evaluation.
\end{abstract}

Keywords: rabbit, healing, herbal medicine, tension, wheat

\section{RESUMO}

O extrato de trigo (Triticum sp.) vem sendo usado na cicatrização de feridas por estimular a síntese de fibroblastos, entretanto a sua aplicabilidade in vivo em apresentações comercialmente viáveis ainda tem de ser demonstrada. Neste estudo, avaliaram-se feridas cutâneas de coelhos tratadas com extrato aquoso de T. aestivum quanto à presença de tecido de granulação e epitelização, estruturas histológicas, qualidade cicatricial, além de ensaio tensiométrico. As feridas foram tratadas diariamente, por 21 dias, com diferentes concentrações do extrato (grupo $I=2 \mathrm{mg} / \mathrm{mL} ;$ grupo $I I=10 \mathrm{mg} / \mathrm{mL}$ ) ou apenas o veículo (grupo controle = creme não iônico), e avaliadas nos dias sete, 14 e 21. A formação de tecido de granulação não diferiu entre os tratamentos. A epitelização aconteceu em menor tempo em feridas do grupo II, mas aos 14 dias já não havia diferença neste parâmetro. Na avaliação histopatológica, a qualidade cicatricial e a força de ruptura não diferiram no período estudado, entretanto a resistência tensiométrica das feridas do grupo I foi maior que a dos demais tratamentos. Dessa forma, conclui-se que, mesmo não havendo diferença na evolução cicatricial de feridas tratadas ou não com extrato aquoso de T. aestivum, o uso desse composto, a $2 \mathrm{mg} / \mathrm{mL}$, resultou em tecidos cicatriciais mais resistentes à tração.

Palavras-chave: coelho, cicatrização, fitoterápico,tensão, trigo

Recebido em 14 de agosto de 2013

Aceito em 10 de junho de 2014

E-mail: mariana.teixeira.tillmann@gmail.com 


\section{INTRODUCTION}

Healing of skin wounds maintains tissue integrity, a process which involves inflammation, proliferation, and maturation (Mcnes et al., 2006). In second intention healing, occlusion of the wound is important; this requires mitotic fibroblasts for the formation of granulation tissue, which will allow growth through migration of epithelial cells to the center of the lesion. The resistance of this tissue is associated with the orientation of collagen fibers and their subsequent maturation. Regarding skin tissue, collagen type I and III are predominant, type I being the most mature and traction resistant (Ferreira et al., 2003; Kahan, et al., 2009; Kim et al., 2013).

Triticum sp. is one of the most important crops in the world (Bandopadhyay et al., 2011). Studies have reported its role in wound healing due to the presence of fitoestimulines acting on fibroblasts. These exert a mitogenic effect on fibroblasts and stimulate the fibroblast's ability to synthesize collagen and glycosaminoglycan (Mastroinanni et al, 1988; Solórzano et al, 2001). There are, however, few experimental studies on the aqueous extract of Triticum in wound healing. In this light, the aim of this study was to assess the healing of wounds treated with creams containing different concentrations of Triticum aestivum (syn. T. vulgare) extract in the rabbit model for wound healing.

\section{METHODS}

Aerial parts of mature wheat were harvested in October 2009 in the city of Jaguarão, Rio Grande do Sul state, Brazil, and sent for botanical identification where the voucher specimen was identified as Triticum aestivum (PEL herbarium, number: PEL24.600). Samples were oven dried and sent to the Centre of Chemical, Pharmaceutical, and Food Sciences Universidade Federal de Pelotas (UFPel) - to be processed. The aqueous extract was obtained from 50 grams of wheat kept under bath ultrasound sonication in $500 \mathrm{ml}$ of distilled water for 30 minutes, at $30^{\circ} \mathrm{C}$. The resulting extract was filtered and its fenolic components were assessed through High Pressure Liquid Chromatography (HPLC-DAD). Fourteen phenolic compounds were used as standards in the screening process, positive compounds were further quantified. After obtaining the aqueous extract of $T$. aestivum, this was homogenized with nonionic cream and used for the treatment of experimental wounds, at $2 \mathrm{mg} / \mathrm{ml}$ and $10 \mathrm{mg} / \mathrm{ml}$ concentrations.

This study was approved by the committee for ethics and animal welfare of UFPel (Comite de Ética em Experimentação Animal - CEEA case number 5104). Twenty-four male rabbits (New Zealand white), weighing 2-3kg, from UFPel Central Animal Facility (Biotério Central) were kept in individual cages under appropriate animal welfare conditions. The animals received dissociative anesthesia (xylazine $5 \mathrm{mg} / \mathrm{kg}$ and ketamine and $75 \mathrm{mg} / \mathrm{kg}$ ) and a number eight punch was used to produce three experimental wounds in each flank (6 wounds/animal), thus producing 144 experimental wounds. All animals were treated with analgesics (2mg of tramadol clorhidrate/kg, every 12 hours, subcutaneously) after surgery, for three days.

The wounds were randomly divided into three groups according to treatment. Wounds in group I were treated with cream containing the aqueous extract of T. aestivum at $2 \mathrm{mg} / \mathrm{ml}$. Those in group II treated were with cream containing $10 \mathrm{mg} / \mathrm{mL}$, and those in group III were treated with nonionic cream (control). Enough cream was used so as to completely cover the wound, operators were blinded to treatment groups. Wound dressings were performed every 24 hours by first cleaning the wound with $0.9 \%$ saline solution, followed by one of the treatments used in this study. Wound protection was then performed with hydrophilic gauze and surgical cloth, which was changed daily. Animals were euthanized after seven, 14, and 21 days, according to Brazilian animal welfare recommendations (Conselho Federal de Medicina Veterinária, 2012).

Clinical assessment was carried out in ten wounds from each group on days seven, 14, and 21. Granulation tissue and epithelialization were observed, and presence or absence of either was considered. At 21 days the quality of wound healing was assessed and ranked into hypertrophic and normotrophic. Evaluators were blinded to treatment groups in all assessments.

After seven, 14, and 21 days, five animals were euthanized and ten skin samples from each treatment group were collected, these were 
placed in a vial containing $10 \%$ formalin and sent to the Histotology laboratory in the Department of Animal Pathology, UFPel. The tissue fragments were processed, imbedded into paraffin and subsequently cut five microns thick and stained with hematoxylin and eosin. The stage of healing (inflammatory, proliferative and maturation), with the amount and pattern of collagen, were assessed according to the following criteria: Inflammatory phase predominance of inflammatory cells with little or no fibroplasias and angiogenesis. Proliferative phase - decrease in the inflammatory infiltrate and increased numbers of fibroblasts in the collagen matrix. Collagen, in thin and/or disorganized fibers. Maturation phase - little or no inflammatory infiltrate. Increased amounts of organized collagen fibers (Figure 1). Specifically, collagen fibers were considered to be present (high or low amounts) or absent; and organized (fibers in a harmonic orientation) or disorganized (fibers with no apparent orientation).

In the tension strength and rupture strength assays, skin samples were cast in hourglass shaped metal molds to obtain the skin models. The mold ensured that there were two ends to attach to the equipment and the wound in the union of the vertices, leaving no adjacent skin to the wound region. The analysis was performed at 21 days of treatment with 15 skin samples from each treatment group. Samples were sent in vials with $0.9 \%$ saline solution to the Centre for Development and Control of Biomaterials, Dentistry College, UFPel. Skin samples were subjected to tensile forces in a universal testing machine (DL 500, Emic, São José dos Pinhais, PR, Brazil) at a cross-head speed of $5.0 \mathrm{~mm} / \mathrm{min}$. TBS values, in Mega-Pascal (MPa), were obtained by dividing the force, in Newton $(\mathrm{N})$, by the calculated area, in $\mathrm{mm}^{2}$.

For the statistical assays, analysis of variance and Tukey's test were used to compare means in the clinical evaluation. In the histopathological, tensiometric and rupture strength evaluations, the Kruskal-Wallis test was used (Statitix 9.0).

\section{RESULTS}

The hydrophilic extract was obtained, as expected, at approximately $10 \mathrm{~mL}$ for every gram of dry T. aestivum matter. The major components found in this extract were: quercetin $(77 \mathrm{mg} / \mathrm{g})$, kaempferol (163 mg/g), apigenin (38mg/g) and carnosic acid (117mg/g).

Clinical assessment revealed that different treatments did not influence the evolution of granulation. On the other hand, epithelialization occurred sooner in animals treated with T. aestivum extract. Scar tissue quality on day 21 showed 80\% normotrophic and 20\% hypertrophic wounds in all groups. On day 7 , wounds treated with aqueous extract of $T$. aestivum at $10 \mathrm{mg} / \mathrm{ml}$ differed from the other treatments $(\mathrm{P}<0.05)$. This occurred due to a lower percentage of epithelialized lesions (58.30\%) compared to those treated with aqueous extract of $T$. aestivum at $2 \mathrm{mg} / \mathrm{ml}$ (68.3\%), and with nonionic cream alone (66.7\%).

Histopathological assessment demonstrated that the wounds were within the physiologically expected pattern at the beginning of the experiment, and were all in the inflammatory phase by day 7. In the middle of the experiment wounds were predominantly in the proliferative phase, with no difference between groups by day 14. However, while groups I and II still had wounds in the inflammatory phase on day 14, this was not observed in the control group, furthermore, all groups had wounds on the maturation phase. At 21 days, groups I and II showed $100 \%$ of the wounds in the maturation phase, while group III (control) had 90\%.

The inflammatory phase was considered when predominantly inflammatory cells were found, usually macrophages and neutrophils, fibroplasia was poor or absent, as was angiogenesis. Proliferative phase was characterized by a decrease in the inflammatory infiltrate and increased numbers of fibroblasts in the collagen matrix. The amount and distribution pattern of the collagen fibers were shown to form, usually, thin and disorganized fibers, and epithelization was characterized as total or partial. Furthermore, the decrease or absence of crust was common in the proliferative phase. In the maturation phase, there was a decrease in the density of fibroblasts, and a reorganization of the collagen matrix, which appeared more abundant and arranged in dense bundles, with wellorganized parallel fibers. In this phase the inflammatory cells were scarce or absent with ample epithelialization (Fig. 1). 


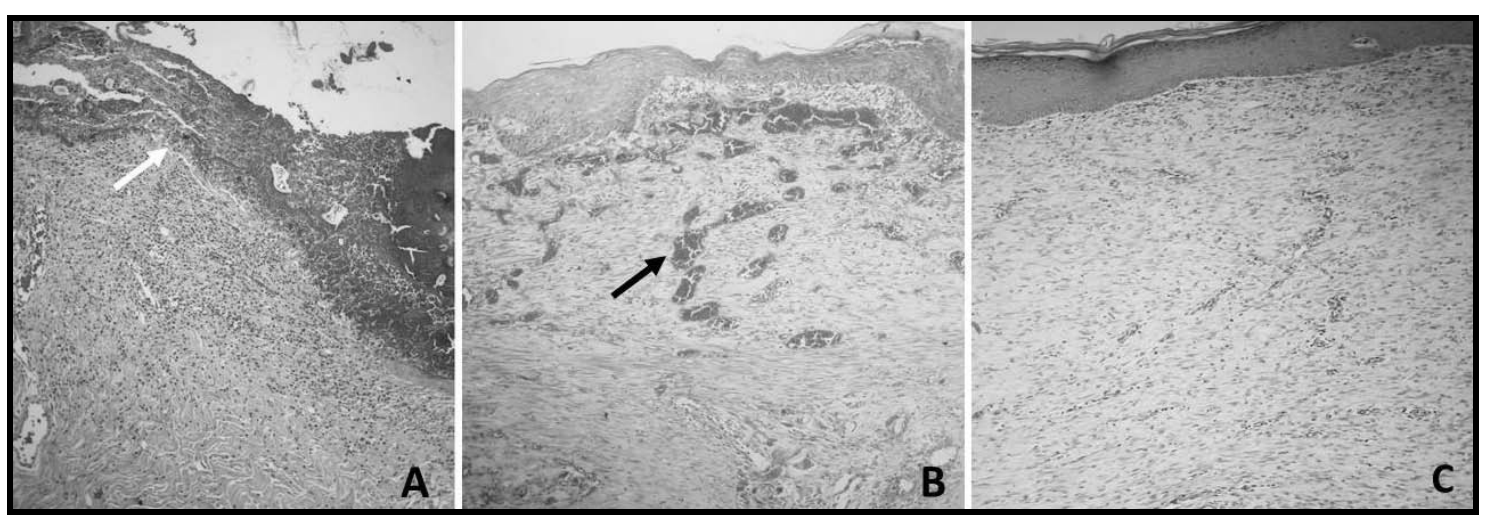

Figure 1. Sample of the histopathological assessment (100x) of the skin healing process of experimentally generated wounds in the rabbit model. Different wound healing phases had these main findings. A: Inflammatory phase of wound healing on the seventh day of treatment, characterized by abundant inflammatory infiltrate and a fresh, unattached crust (white arrow). B: Proliferative phase of wound healing in the fourteenth day of treatment, characterized by a disorganized connective tissue with intense angiogenesis (black arrow) and a new epidermis. C: Maturation phase on the twenty-first day of healing, characterized by an organized connective tissue and a mature epidermis with keratinized outer layer.

Collagen evaluation revealed no difference between groups throughout the study. At seven days, groups I, II, and III showed collagen in high quantities and fine pattern. Progressing at 14 days to collagen in high quantities and dense pattern, and at 21 days they evolved into a collagen formation in low amounts and dense pattern.

There was no statistically significant difference in rupture strength at 21 days of healing. However, group I did show a higher overall mean $(45.6 \mathrm{~N})$ when compared to groups II (35 $\mathrm{N})$ and III (33.5 N). In the tensiometric analysis group I had a statistically higher mean $(1.6 \mathrm{~Pa})$, when compared to groups II (1.3 Pa) and III (1.2 Pa) $(P<0.05)$.

\section{DISCUSSION}

The results described in this study show that, while the aqueous extract of $T$. aestivum did not hasten the healing process, it did, when applied at $2 \mathrm{mg} / \mathrm{mL}$, increase the tensiometric strength of the healed tissue. Furthermore, the use of higher concentrations of the extract $(10 \mathrm{mg} / \mathrm{mL})$, delayed the onset of epithelialization to the second week, when compared to a low dose $(2 \mathrm{mg} / \mathrm{mL})$ or control. This difference in the clinical analysis of epithelialization may have occurred because a high concentration of the agent will induce strong pro inflammatory action. This leads to greater cellular migration into the injured site of the wounds treated with $10 \mathrm{mg} / \mathrm{mL}$ than those treated with $2 \mathrm{mg} / \mathrm{mL}$, causing a longer inflammation phase and thus a delay in the formation of epithelial tissue (Souza et al., 2006).

Scar quality was similar in all treatments, possibly because clean wounds heal in less time and with satisfactory aesthetic effect. For this it needs humidity, and all treatment groups had a cream base, promoting a moist environment that allows cell migration and the formation of a normotrophic scar (Wolfram et al., 2009). Likewise, histopathological assessment revealed cell patterns and collagen fibers evolving according to what would be expected for the different healing phases (Fig. 1) (Kahan et al, 2009; Kim et al., 2013). The evaluation of the collagen fibers also showed a progressive pattern of maturity in the assessed period.

Major active components found in our $T$. aestivum extract were quercetin, kaempferol, apigenin and carnosic acid. The first three were expected, common in wheat, they are responsible for a series of biological effects, with antioxidant and anti-inflammatory action (Santos et al., 2011). The carnosic acid however, is a common component of rosemary (Rosmarinus officinalis), which has also had antioxidant proprieties described (Posadas et al., 2009). Wheat extracts have a pro-inflammatory action (Souza et al., 2006), increasing fibroblast migration into the injured site. This may have influenced the 
observed effect on day 14, where some lesions treated with the herbal extract, but not those of the control, were still in the inflammatory phase. On other hand, it was found that at the end of the experiment all wounds treated with cream containing wheat were in the maturation phase, while this was not observed in wounds treated only with non-ionic cream. Thus it is likely that the pro-inflammatory action does not interfere with the wound's final maturity.

Regarding the rupture strength test, the force required to break the healed skin was similar in all treatments. Conversely, in the tensiometric analysis, the aqueous extract of $T$. aestivum at $2 \mathrm{mg} / \mathrm{mL}$ yielded better results, possibly due to having a higher percentage of type I collagen than the wounds of the other groups (Kahan et al., 2009). The tension of scar tissue depends on the type, quantity and orientation of collagen fibers (Kahan et al, 2009; Kim et al., 2013). In this study we show that the amount and pattern of collagen did not differ among treatments, however, the type of collagen fibers was not assessed. Variation in collagen type would be the most likely explanation for the difference in tension strength observed. While greater tension is a positive trait, the treatment in question $(2 \mathrm{mg} / \mathrm{mL})$ did not present any further advantages, and these extracts should be studied further before they can be deemed commercially or medically viable.

\section{CONCLUSION}

The results obtained in this study show that cream containing aqueous extract of $T$. aestivum at $2 \mathrm{mg} / \mathrm{mL}$ induces a healing process that stimulates a higher tensiometric strength than the control or the same extract at $10 \mathrm{mg} / \mathrm{mL}$, when assessed in the rabbit model of wound healing. No other difference was observed among treatments in the parameters considered; however, collagen type should be assessed in future studies.

\section{ACKNOWLEDGMENTS}

CNPq (305072/2012-9) for funding the project 481605/2010-0. CNPq and CAPES for financial support and scholarships. The authors thank Ana Paula Pinheiro Pereira for technical support in the formulation of the treatments, and the animal facility staff for their support.

\section{REFERENCES}

BANDOPADHYAY, R.; RUSTGI, S.; CHAUDHURI, K. et al. Use of methylation filtration and $\mathrm{C}_{0} \mathrm{t}$ fractionation for analysis of genome composition and comparative genomics in bread wheat. J. Genet and Genom., v.38, p.315-325, 2011.

FERREIRA, E.; SERAKIDES, R.; NUNES, V.A. et al. Morfologia e histoquímica da pele de ratas hipotireoideas castradas e não castradas. Arq. Bras. Med. Vet. Zootec., v.55, p.51-60, 2003.

KAHAN, V.; ANDERSEN, L.; TOMIMORI, J. et al. Stress, immunity and skin collagen integrity. Brain, Behav, and Imm., v.23, p.1089-1095, 2009.

KIM, J.; CARVALHO, C.; SOUZA, A. et al. Topical application of the lectin Artin $\mathrm{M}$ accelerates wound healing in rat oral mucosa by enhancing TGF- $\beta$ and VEGF production. WRR., v.21, p.456-463, 2013.

MASTROIANNI, A.; CELLENO, L.; BORGIA, M.G. et al. Léstratto acquoso di 'Triticum vulgare"'valutazione clinico-istologica Nei processi riparativi tissutali cutanei. G Ital .Derm. Venereol., v.133, p.145-153, 1988.

MCNES, P. Skin and wound assessment and care in oncology. Oncol. Nurs., v.22, p.130-143, 2006.

POSADAS, J.; CAZ, V.; LARGE, C. et al. Protective effect of supercritical fluid Rosemary extract, Rosmarinus officinalis, on antioxidants of major organs of aged rats. Exp. Geront., v.44, p.383-389, 2009.

CONSELHO FEDERAL DE MEDICINA VETERINÁRIA-CFMV. RESOLUÇÃO $\mathrm{N}^{\mathrm{o}} 1000$, de 11 de maio de 2012.

SANTOS, S.; GONVALVES, L.; VAISMAM, M. et al. Impacts of flavonoids on thyroid function. Food Chem Toxic., v.49, p.2495-501, 2011.

SOLÓRZANO, O.T.; HURTADO, H.R.; LÓPEZ, J.L.V. et al. Evaluación de la actividad reepitelizante del Triticum vulgare en la cervicitis crônica erosiva. Rev. Fac. Med. UNAM., v.44, p.79-83, 2001.

SOUZA, W.; MACHADO, L.; ZOPPA, V. et al. Ensaio da aplicação de creme à base de Triticum vulgare na cicatrização de feridas cutâneas induzidas em equinos. Rev. Bras. Pl. Med. v.8, p.9-13, 2006.

WOLFRAM, D.; TZANKOV, A.; PÜLZL, P.; PIZAKATZER, H. Hypertrophic scars and keloids - a review of their pathophysiology, risk factors, and therapeutic management. Dermat. Surg., v.35, p.7181, 2009. 